\title{
CS-41 - Aplicación móvil para el aprendizaje de verbos en inglés
}

\author{
Mobile app for learning english verbs \\ Nelson Javier Cetz Canché*, Juana Magnolia Burelo Burelo, María Evilia Magaña, Isaías Hernández \\ Rivera, Jorge Alberto Ceballos García
}

División Académica de Informatica y Sistemas, Universidad Juárez Autónoma de Tabasco, México

*Autor a quien se dirige la correspondencia: nelson.cetz@ujat.mx

\section{Resumen}

$\mathrm{C}$

on el surgimiento de las nuevas tecnologías el ser humano ha experimentado cambios radicales en todos los contextos de su quehacer; por ejemplo, la comunicación, el esparcimiento, la forma de producción y la educación, entre otros. Muchos de estos cambios han sido posibles gracias al rápido avance de las tecnologías de la información y comunicación (TIC) en las últimas décadas. En este trabajo se plantea adoptar una aplicación móvil, que aprovechando las ventajas de las TIC, y refiriéndose en específico a estudiantes de la Licenciatura en Informática Administrativa, en la asignatura de Lengua Extranjera de la División Académica de Informática y Sistemas, Universidad Juárez Autónoma de Tabasco, México (DAIS-UJAT), puedan acceder a los contenidos a cualquier hora y en cualquier lugar donde tengan acceso a este medio tecnológico.El proceso de investigación para este estudio se abordó desde un enfoque mixto, no obstante que se emplea la combinación de los enfoques cuantitativos y cualitativos, y respetando los métodos inherentes a cada enfoque, asimismo, mediante la encuesta y aplicación de un cuestionario se obtiene información objetiva de los estudiantes, para evaluar el grado en que una nueva estrategia didáctica de tipo tecnológica se incorpore al proceso educativo y favorezca el aprendizaje.

Palabras claves: Aplicación móvil, aprendizaje, tecnologías de la información y comunicación, conocimiento, modelo educativo

\section{Abstract}

$\mathrm{W}$ ith the emergence of new technologies the human being has undergone radical changes in all the contexts of his work, for example, communication, entertainment, production and education, among others. Many of these changes have been made possible thanks to the rapid advance of information and communication technologies in the last decades. In this paper we propose to adopt a mobile application, taking advantage of the advantages of ICTs, and referring specifically to students of the Degree in Administrative Computer Science, in the subject of Foreign Language of the División Académica de Informática y Sistemas, Universidad Juárez Autónoma de Tabasco, México (DAIS-UJAT), can access the contents at any time and in any place where they have access to this technological medium. The research process for this study was approached from a mixed approach, although the combination of quantitative and qualitative approaches is used, respecting the methods inherent to each approach, and the survey and application of a questionnaire is obtained Objective information of the students, to evaluate the degree to which a new didactic strategy of technological type is incorporated in the educational process and favors the learning.

Key words: Mobile application, learning, information and communication technologies, knowledge, educational model 